\title{
Contrived Self-Defense: A Case of Permissible Wrongdoing
}

This is a preprint of an article published in PHILOSOPHICAL FORUM.

The final authenticated version is available online at: https://doi.org/10.1111/phil.12298

\begin{abstract}
It is widely held that a morally wrong action is morally impermissible. I discuss a case of contrived self-defense and argue that it is morally both wrong and permissible. I compare it with other kinds of morally permissible misbehavior (suberogation, moral dilemma, and right to do wrong) and show that it is significant and original.
\end{abstract}

KEYWORDS: permissible wrongdoing; moral dilemma; suberogation; right to do wrong; self-defense; blame 
It is commonly held — even considered a conceptual truth — that an action is morally wrong, if and only if it is morally impermissible (Darwall, 2013, 28; Kamm, 2012, 181; Scanlon, 2008, 7). Since one point of morality is to guide people's actions, it seems pointless to tell people what they are doing is wrong, but then give the green light to their actions anyway. Nevertheless, there are morally permissible wrongdoings, at least in common-sense morality. The qualification is added because I accept that some moral theories would consider the case I am going to discuss as either wrong or permissible. But I think that my case has the intuitive appeal of being a case of morally permissible wrongdoing. My aim here is to demonstrate this intuitive appeal. Some philosophers may argue that we should revise our moral theories to rule it out. I don't oppose them, but I want to establish that the idea of my case being a distinct type of permissible wrongdoing should be taken seriously.

The case of permissible wrongdoing I am to examine is as follows:

Contrived Self-Defense. Mike and Don each are a member of two rival gangs. Mike plots to kill Don, who Mike knows is bad-tempered and always carries a gun. So Mike hides a gun with him and goes to provoke Don. As expected, Don gets angry and pulls a gun on Mike. But as soon as there is a clear sign that Don threatens Mike's life, Mike shoots Don, which kills him.

In essence, Mike's killing Don is a case of both murder and self-defense. It is a case of murder because it is intentional and premeditated. Murder, especially out of personal feud, is surely morally wrong. Nevertheless, Mike is also permitted to defend himself by killing Don because Don is posing a deadly threat to him. Thus, Contrived Self-Defense is both morally wrong and morally permissible. ${ }^{1}$ This rationale is what I take to be behind the intuition about Contrived Self-Defense as a case of permissible wrongdoing.

\footnotetext{
${ }^{1}$ Given the nature of Contrived Self-Defense, one may try to explain away my intuition by arguing that this case is not morally permissible, but merely legally permissible. I want to stress that my concern is moral. None of the arguments I offer is legal in nature.
} 
In the following, I will first defend the permissibility of Contrived Self-Defense by appealing to three recent accounts of self-defense (section 1). I then argue for the wrongness of Contrived Self-Defense by arguing that it is appropriate to blame Don's death on Mike (section 2). Therefore, Contrived Self-Defense is a case of permissible wrongdoing.

Now, some might think that the fact that Contrived Self-Defense is wrong (or permissible) shows that the accounts of self-defense in section 1 (or the account of blameworthiness in section 2) should be rejected or revised. However, this response assumes that all wrongdoings are impermissible (and vice versa). But moral philosophers do recognize the possibility of certain types of permissible wrongdoing — most notably, moral dilemma and the right to do wrong. So, it would be wrong to reject a moral theory simply on that grounds. By comparison with them, in section 3, I argue that Contrived Self-Defense is a distinct type of permissible wrongdoing.

Thus, one should not deny the permissibility (wrongness) of Contrived Self-Defense simply because it is wrong (permissible), since that is what is at issue here. Likewise, for those who are familiar with the literature in philosophy of criminal law would know that there is a number of discussion of cases like Contrived Self-Defense (known as actio libera in causa cases). Given their interest, their debates are mostly on whether Mike's killing Don is permissible or his right to self-defense is forfeited (Alexander, 2013; Farrell, 2013; Ferzan, 2013; Finkelstein \& Katz, 2008; Hecht, 2019). But they rarely discuss whether Contrived Self-Defense is a case of wrongdoing. Very likely, they do not think that the answers to the two questions would be different. However, it is worthwhile to examine whether it is a case of permissible wrongdoing, especially since it would be an original type of wrongdoing that moral philosophers have not noticed yet. Therefore, I urge the readers not to take some of those philosophers' views that Contrived SelfDefense is permissible (or wrong) to suggest that my account is false. On the contrary, the opposite views of experts could very well support the plausibility of my view (I will discuss some of their views below).

To pre-empt potential confusion, I want to stress that the object under evaluation is Mike's killing Don, not merely Mike's plotting to kill Don. Some might try to explain away my intuition by maintaining that what 
is wrong in this case is Mike's plotting to kill Don, but his killing Don, despite that, is not wrong and thus permissible. ${ }^{2}$ Of course, it is wrong for Mike to plot against Don. But my thesis is that Mike's killing Don by means of contrived self-defense is both wrong and permissible. If you think that it is permissible and thus not wrong on the grounds that it is self-defense, I urge you to attend to the fact that it is also a clear case of murdering, especially for his self-interests that cannot justify killing (and vice versa).

Therefore, Contrived Self-Defense is morally problematic and bizarre because my arguments will show that there are two equally strong and valid moral considerations pulling us in opposing directions. It seems that Mike could justify his killing Don, but punishing him for Don's death seems also justified. I do not know how to solve this puzzle, but my purpose is to show that the puzzle is there.

1. The Permissibility of Contrived Self-Defense

To show that Contrived Self-defense is, intuitively, permissible, I discuss three prominent accounts of selfdefense by Daniel Farrell (2013), Helen Frowe (2014), and Jonathan Quong (2015), all of which, I argue, would render the verdict that Contrived Self-Defense is permissible. These accounts of self-defense are not revisionary, that is, they are not trying to revise our commonsensical view about the right to self-defense. The fact that three non-revisionary accounts of self-defense will conclude that Contrive Self-Defense is permissible is good evidence that it is intuitively so.

Let me begin with Farrell. Farrell is the only one among them who argues that Contrived Self-Defense is permissible on the grounds of his account of self-defense: ${ }^{3}$

\footnotetext{
${ }^{2}$ Larry Alexander (2013) appears to hold this view. He argues that Mike's action before his killing Don is wrong, but he is permitted to kill Don. He doesn't explicitly argue that it is not wrong.

${ }^{3}$ While defending its permissibility, Farrell suggests that people who commit to Contrived Self-Defense ought to be punished because it is morally problematic (which I discuss later). So it appears that Farrell
} 
(FSD) When someone knowingly brings it about, through his own wrongful conduct, that someone else must choose either to harm him or to be harmed herself, justice allows the latter to choose that the former shall be harmed, rather than that she shall be harmed, at least if the harm inflicted on the former is not radically disproportionate to the harm that would otherwise be inflicted on the latter. (Farrell, 2013, 573)

Farrell argues that Mike's killing Don satisfies FSD because, first, Mike's shooting Don is proportionate to the threat Don poses to Mike; second, Don's threat to Mike, which is wrong, brings about the situation that Mike must choose either to harm Don or to be harmed himself. Therefore, Mike is permitted to defend himself by shooting Don, which kills Don.

For the sake of argument, I assume that Mike's reaction satisfies the proportionality requirement because Don's threat could be lethal. The crucial question then is whether the second part of Farrell's rationale is correct. It can be divided into two questions: first, is Don's threat to Mike wrong? Second, does Don's threat bring about the situation that Mike must choose either to harm Don or to be harmed himself?

With regard to the first question, one may think that Don is right to threaten Mike because Mike deliberately provokes Don. But in Contrived Self-Defense, Farrell points out, it is stipulated that Mike's provocation must be relatively mild with respect to Don's threat. Presumably, what Mike does is just verbally insulting Don. If Don did not pull out his gun, Mike would have to refrain from increasing the intensity of his provocation to get Don falling into his scheme. Given that it is stipulated that Don's threat far exceeds Mike's provocation, Don's threat is wrong.

With regard to the second question, one may think that it is Mike who puts himself into the situation that he receives the threat from Don, so it is not Don that brings about that situation. Farrell responds that it is nevertheless Don himself that chooses to pull out his gun. While Mike's provocation induces Don to pull

would think that Contrived Self-Defense is a case of permissible wrongdoing. However, he does not argue for this claim. 
out his gun, Don remains a free agent who could control himself from threatening Mike too severely. Presumably, Don could keep his temper and react to Mike's provocation more mildly. In other words, because of the threat he chooses to pose on Mike, Don is also responsible for the situation that Mike must choose whether to defend himself.

To be clear, Farrell does not mean that Mike has no responsibility for letting himself into that situation. Instead, he maintains a shared responsibility view:

We have stipulated that T [Don's equivalent] is responsible for choosing to physically attack M [Mike's equivalent] because of his insult (I am assuming, as indicated earlier, that, taken in isolation from the fact of M's strategic plan, such an attack is not warranted, morally, even if dressing him down verbally would be warranted), but we have also stipulated (or are assuming) that $\mathrm{T}$ is in a situation where she has occasion even to consider attacking M only because of M's decision to put her in such a situation in the first place - that is, only because of his decision to put her in that situation in order to have the opportunity to harm her and then escape the legal consequences of doing so by claiming "self-defense". (Farrell, 2013, 578)

Although Mike is partially responsible for putting himself into the situation that he must choose whether to defend himself, it remains true that Don is also responsible. Hence, according to FSD, Mike is permitted to kill Don.

Let me now consider Frowe's account. Frowe maintains that $\mathrm{S}$ is liable to defensive harm if and only if $\mathrm{S}$ is "morally responsible for posing an unjust threat" $(2014,73)^{4}$ and the defensive harm inflicted upon S must be proportionate means of averting the threat posed by $\mathrm{S}$ (Frowe 2014, 105). Moreover, $\mathrm{S}$ is morally responsible for posing the unjust threat if $\mathrm{S}$ "intentionally fails to avail herself of a reasonable opportunity

\footnotetext{
${ }^{4}$ Instead of offering a necessary and sufficient condition for liable defensive harm, what Frowe in fact offers is merely a necessary condition (an "only if" conditional). However, Frowe treats it as a sufficient condition as well. For example, see (Frowe, 2014, 76, 84). Therefore, I modify Frowe's account accordingly.
} 
to avoid posing the threat" $(2014,86)$. And S intentionally fails to avail herself of a reasonable opportunity to avoid posing the threat if the following conditions are met:

(a) The victim has a right not to suffer the harm;

(b) $\mathrm{S}$ believes that a given course of action will endanger the victim (who has a right not to be harmed);

(c) $\mathrm{S}$ believes that $\mathrm{S}$ has at least one alternative course of action that would not so endanger the victim, and the alternate action is not unreasonably costly for $\mathrm{S}$;

(d) $\mathrm{S}$ believes that $\mathrm{S}$ chooses not to take that alternative course of action. (Frowe, 2014, 86)

Frowe should think that Contrived Self-Defense is permissible because Don's reaction satisfies these conditions. Don certainly knows that pulling out his gun (or other kinds of lethal threat) is not the only possible response to Mike's provocation: he could walk away or insult Mike back, or he could even punch Mike in the face, which are not unreasonably costly for Don. Don also knows that he chooses to pull out his gun instead of the above alternatives and that his threat could severely harm or even kill Mike. Hence, (b)-(d) are satisfied.

Whether (a) is satisfied in Contrived Self-Defense is more complicated. One may think that Mike forfeits the right not to suffer the harm from Don because Mike is executing his murder plan. Accordingly, Mike is liable to defensive harm from Don, and thus (a) is not satisfied.

But Frowe's account can, in turn, explain why (a) is satisfied. To see this, let's wind the clock back to the moment before Don pulls his gun on Mike: clearly, Mike's provocation also satisfies (a)-(d), so Mike is liable to defensive harm from Don. But Don's liable defensive harm must satisfy the proportionality condition. Since Don's reaction far exceeds Mike's provocation, Mike is not liable to Don's lethal threat to him, which means that Mike still has the right not to suffer from Don's threat. Therefore, Don is liable to defensive harm from Mike because Don's reaction satisfies (a)-(d) and Mike's shot is proportionate means of averting Don's threat. Hence, Frowe should judge that Mike is permitted to kill Don. 
Let me turn to Quong. Quong develops an evidence-based account of defensive harm: according to Quong, A has a right against B's $\varphi$-ing if and only if it is reasonable for A to demand of B not to $\varphi \cdot{ }^{5}$ And the question whether A has a right against B's $\varphi$-ing can only be assessed "by reference to abilities and information that can reasonably be expected to be available to [B] in a given situation" (Quong, 2015, 257). ${ }^{6}$ "Reasonableness," according to Quong, "is a moralized notion that takes into account the interests and status of all affected parties," which include:

(i) The value of the activity $B$ engages in by $\varphi$-ing;

(ii) How costly it would be for B to refrain from $\varphi$-ing;

(iii) Whether B had sufficient opportunity to avoid finding himself in a situation where he faces the choice whether or not to $\varphi$;

(iv) Whether A had sufficient opportunity to avoid finding himself in a situation where he might be harmed by B's $\varphi$-ing. (Quong, 2015, 255)

The list is not exhaustive. But it gives us enough idea to judge whether A's demand is reasonable from B's perspective. It appears, according to Quong's account, that Mike has the right against Don's threat because it is reasonable, from Don's perspective, that Mike demands him not to threaten Mike's life because Don's threatening Mike's life satisfies (i)-(iv). Don's reaction has great disvalue. It is not costly for Don to refrain

\footnotetext{
${ }^{5}$ Frowe $(2015,268)$ interprets Quong, like her (see note.3), as offering a necessary condition for defensive harm. However, Quong is unclear on this matter; while Quong initially considers only a necessary condition for liable defensive harm, he eventually treats it as a sufficient condition as well (Quong, 2015, 263-265) ${ }^{6}$ I follow Frowe (2015) who, correctly in my opinion, interpret Quong's view as the claim that whether A's demand is reasonable must be judged from B's perspective. Quong's text is less clear on this matter.
} 
from threatening Mike's life. ${ }^{7}$ Don could choose not to pull out his gun; he could walk away or shout back. Finally, after pulling out his gun, it is clear, from Don's perspective, that Mike does not have enough opportunity to avoid the possibility that he could be harmed by Don. Therefore, it is reasonable for Mike to demand Don not to threaten his life; according to Quong, Mike has the right to inflict defensive harm against Don.

I have discussed three prominent accounts of self-defense. All deliver the verdict that Mike is permitted to kill Don, even though he is executing a murder plan. Given the non-revisionary nature of these accounts, the result should be enough to show that Contrived Self-Defense is intuitively permissible.

To reject the permissibility of Contrived Self-Defense, I suspect that some may appeal to the doctrine of double effect to argue that Mike's killing Don is impermissible since he intends to kill Don rather than foresees Don's death as a side-effect of defending himself. Or less radically, some may argue that Mike's killing Don is impermissible since he is executing the plan for murdering Don. For example, Kimberly Ferzan (2013) and Claire Finkelstein and Leo Katz (2008) argue that people like Mike forfeit the right to self-defense because they start the fight and thus make themselves liable for the attack. However, it does not seem right. To see that, consider a modified version of Contrived Self-Defense:

Mild Provocation. Mickey and Donnie each are a member of two rival gangs. Mickey plots to kill Donnie, who Mickey knows always carries a gun. Mickey also knows that Donnie is bad-tempered and has long-standing animosity towards him, to the extent that Donnie is likely to attack him if they meet. So Mickey hides a gun with him and deliberately shows up where Donnie could see him (but Mickey has no confrontation with Donnie). As expected, Donnie gets mad and pulls a gun on Mickey. But as soon as there is a clear sign that Donnie threatens Mickey's life, Mickey shoots Donnie, which kills him.

\footnotetext{
${ }^{7}$ One may worry that it might be emotionally costly for Don given his psychology. For my purpose, I can stipulate that the emotional cost is not so great as to make Don's threatening Mike's life reasonable.
} 
To say that Mickey is not permitted to defend himself because he intends or attempts to murder Donnie is to completely ignore the fact that Mickey's provocation is so mild and Donnie's reaction far exceeds Mickey's provocation. Therefore, I think that this response overlooks the proportionality requirement that should be in any plausible account of the right to self-defense. As Lisa Hecht recently replies to Ferzan, "This [response] seems to be getting things the wrong way around. After all, the aggressor does more wrong than the provocateur. It is an odd implication of Ferzan's account that the aggressor should be in a better position with respect to defensive rights than the provocateur despite acting more wrongly" (Hecht, 2019, 172).

However, Hecht also proposes a sophisticated account that seems to suggest that Mike couldn't kill Don.

A provocateur contributes to the creation of a partially excused unjust threat and therefore forfeits some of her defensive rights... The provocateur and the respondent share responsibility for the threat, but how those shares are distributed might vary. However, I argued that the provocateur will not forfeit all her rights against harm and will still be allowed to self-defend with reduced force. (Hecht, 2019,

Hecht's view is similar to Farrell's in the respect that both maintain that the provocateur and the respondent share responsibility. But Hecht criticizes that Farrell's view cannot "distinguish innocent victims from provocateurs" in terms of how much force they can use to defend themselves (Hecht, 2019, 181). For Hecht, while a provocateur still retains some right to self-defense, the force he can use to defend himself must be reduced in comparison to an innocent victim. Accordingly, Hecht seems to suggest that Mike must use reduced force - that is, non-lethal force — to counter Don's threat. Therefore, Hecht might argue that Contrived Self-Defense is impermissible.

Nevertheless, Hecht's account could be compatible with mine. For what if the only way for the provocateur to defend himself against a lethal threat is to use lethal force? Hecht says that the answer depends on which way can minimize wrongful harm; in her words, "closer inspection would also tell us who of the two has more responsibility and so forfeits more of his rights" (Hecht, 2019, 183). Accordingly, it could be the case 
that Mike is still permitted to kill Don since his provocation is much milder than Don's threat (this is particularly the case in Mild Provocation).

I do not mean that no theory of self-defense could plausibly deny Mike the right to self-defense. But my aim in this section is merely to establish the intuitive appeal that Contrived Self-Defense is morally permissible. And the fact that several intuitively plausible theories of self-defense would support the permissibility of Contrived Self-Defense shows that the appeal is genuine.

\section{The Wrongness of Contrived Self-Defense}

Granted that Mike has the right to self-defense against Don's threat, another line of objection is to argue that Contrived Self-Defense is not wrong. But how can it be the case? Contrived Self-Defense is undoubtedly a case of murder out of personal feud. Intuitively, it is wrong.

For those who do not share my intuition, let me develop another argument for the wrongness of Contrived Self-Defense. My argument is based on the relation between wrongdoing and blame. Intuitively, Mike is blameworthy for killing Don because he is partially responsible for it. Since blameworthiness often implies wrongdoing, it is tempting to conclude that Mike's killing Don is wrong.

However, blameworthiness does not entail wrongdoing. Consider a prominent account of blameworthiness:

(BW) $\mathrm{S}$ is blameworthy for $\varphi$-ing, if and only if $\varphi$-ing manifests a morally objectionable quality of will on the part of S. (Capes, 2012; Graham, 2014) ${ }^{8}$

Since it is possible that an action manifests a morally objectionable quality of the agent's will without being wrong, BW maintains that an agent can be blameworthy without committing wrongdoing. Accordingly, the blameworthiness of Mike's killing Don does not entail that it is wrong.

\footnotetext{
${ }^{8}$ Capes initially takes the quality of will as a necessary condition for blameworthiness $(2012,432)$. But later he endorses it as a sufficient condition as well $(2012,434)$.
} 
Is BW true? BW can be supported by a category of moral standing: suberogation (which is bad, but permissible). Suberogatory actions, as Julia Driver explains, are "deserving of negative evaluation, without being actually wrong, where 'wrong' just means 'impermissible'" (1992, 286 n.2). ${ }^{9}$ To use an example from Driver to illustrate the notion of suberogation:

Train. In boarding a train the person who is first gets first choice of seats. But suppose that the train is almost full, and a couple wishes to sit together, and there is only one place where there are two seats together. If the person ahead of them takes one of those seats, when he could have taken another less convenient seat, and knowing that the two behind him wanted to sit together, then he has done something blameworthy. Yet, if he gives up this seat, and takes a less desirable one, he has done something praiseworthy. The problem is justifying the blame when the agent is acting within his rights. The people who want to sit together have no claim against the person ahead of them in line. Thus, he has no obligation to pass up the more convenient seat. (Driver, 1992, 286287)

Driver's reason why the man's action is suberogatory is that he has no obligation to pass up that seat and the couple has not right against his decision. Despite not being wrong, nevertheless, his action is blameworthy, as BW maintains, because his deliberation of occupying the seat is morally questionable. Similarly, one could maintain that Contrived Self-Defense is suberogatory rather than wrong, though Mike is blameworthy for killing Don.

For the sake of argument, I accept that suberogatory actions are blameworthy and BW is correct. To argue for my thesis, let me propose another principle concerning blaming and wrongdoing:

\footnotetext{
${ }^{9}$ A different account of suberogation is offered by Paul McNamara (2011): $\varphi$-ing is suberogatory if and only if it is (1) permissibly suboptimal (permissible but not the most preferable), (2) blameworthy, and (3) not praiseworthy to not $\varphi$-ing. Contrived Self-Defense is suberogatory according to McNamara's analysis, but it doesn't tell us why Contrived Self-Defense is just suberogatory rather than wrong.
} 
(BLAME) It is correct to blame $\mathrm{x}$ on $\mathrm{S}$, if and only if $\mathrm{S}$ is wrong to $\varphi$ and $\mathrm{x}$ is a negative consequence of S's $\varphi$-ing.

In addition to blaming $\mathrm{S}$ for $\mathrm{x}$, blaming $\mathrm{x}$ on $\mathrm{S}$ usually involves asking $\mathrm{S}$ to take responsibility for $\mathrm{x}$. Asking $\mathrm{S}$ to take responsibility for $\mathrm{x}$ is different from saying that $\mathrm{S}$ is responsible for $\mathrm{x}$. The latter is often a factual statement that $\mathrm{S}$ causes $\mathrm{x}$. Asking $\mathrm{S}$ to take responsibility for $\mathrm{x}$, however, puts forward some normative demands. For example, it could be asking that $\mathrm{S}$ should compensate for the negative consequences brought by $\mathrm{x}$, or that $\mathrm{S}$ should be thus punished. Or when neither compensation nor punishment is called for, $\mathrm{S}$ should face criticisms for causing the negative consequences. ${ }^{10}$

Let's test BLAME on Train. While the man is suberogatory and thus blameworthy for taking the seat, is it correct to blame the separation of the couple on him? The answer, I think, is no. It seems wrong to ask him to take responsibility for their separation. Even if the blame is mild—such as merely criticizing him for that - blaming that on him still seems wrong. For he does have the right to take that seat. When facing criticism, he is rightly replying, for example, "The seats are not reserved. Everyone has the right to take it." Since he is not wrong in taking the seat, the separation of the couple should not be blamed on him.

Accordingly, there is a crucial difference between being blameworthy for $\varphi$-ing and being correctly blamed for the consequence of $\varphi$-ing. In Train, the man is blameworthy for taking the seat. But it does not follow

\footnotetext{
${ }^{10}$ Some may think that Joel Feinberg's unfortunate hiker (Feinberg, 1978) is a counterexample to BLAME. The hiker, facing an unexpected blizzard, broke into your cabin to save his life. It was not wrong of him to damage your property, but you are certainly entitled to ask compensation from him. Nevertheless, this example doesn't challenge BLAME because it's inappropriate for you to blame him. Blaming is more than merely asking him to take responsibility; it's a strong, negative emotional attitude. You are naturally feeling unhappy about your cabin being damaged. But a decent person shouldn't blame the hiker because he was not wrong in doing it for saving his life, though you are entitled to compensation.
} 
that he should be blamed for the separation of the couple. According to BW, the man is blameworthy because his action manifests an objectionable quality of his will. Thus, it may be appropriate to criticize him for being selfish or ill-intentioned, but it is inappropriate to criticize him for causing the separation of the couple. The latter requires further that he is wrong in taking the seat. Therefore, while blameworthiness does not entail wrongdoing, being correctly blamed for the consequence of one's action does entail that one's action is wrong.

Now return to my thesis: Contrived Self-Defense is a case of wrongdoing because Mike should be blamed for Don's death. To be clear, I am not saying that Don's death should be blamed entirely on Mike. As Farrell argues, Mike and Don share the responsibility. To test our intuition, we can ask whether taking any normative action concerning Don's death against Mike is appropriate. One may think that Mike does not need to compensate or be punished because he has the right to defend himself against Don's threat (a tricky issue I will discuss in the next section). Even so, it does not follow that Contrived Self-Defense is not wrong. It could be the case that the responsibility for Don's death falls largely on Don himself rather than Mike, but Mike still shoulders some responsibility. For those who think that punishment or compensation is uncalled for, they would agree that, at least, blaming Don's death partially on Mike is appropriate. If so, then Contrived Self-Defense is wrong.

\section{The Originality of Contrived Self-Defense}

Suppose that I have done enough to prove my thesis. One may think that my view is not really original because there are two known kinds of permissible wrongdoings: first, the right to do wrong; and second, moral dilemma. I explain why Contrived Self-Defense still merits our attention.

Some philosophers (Waldron, 1981; Enoch, 2002) have argued that there are rights to do wrong, such as the right to use hate speech or to vote for a racist party. By definition, these actions are permissible wrongdoings. Since what Mike does is abusing the right to self-defense to murder Don, it seems to be just a case of using one's right to do wrong. 
However, the permissibility of using those rights to do wrong is usually defended on the grounds that they are requisite for autonomy or moral development, as David Enoch explains:

Granting individuals rights is a way—perhaps the way—of respecting personal autonomy. And sometimes the tradeoff between the value of autonomy and other values will justify granting them the right to do what they are morally required not to do. Unless one is willing to accept this result at least on occasion, one is not letting people be the authors of their own lives. (Enoch 2002, 380)

Even if we accept that there could be rights to do wrong for the sake of autonomy or personal development, it cannot be the case that any wrongdoing can be defended on such grounds. To be sure, there is a tradeoff between autonomy and the permissibility of wrongdoing, and the tradeoff must be acceptable. Certainly, Contrived Self-Defense - a case of murder — cannot be defended on the grounds of Mike's autonomy. Instead, Mike is permitted to retain the right to self-defense because Don's threat to him is unjustified. Hence, at least, Contrived Self-Defense is a new and neglected kind of the right to do wrong.

One might think that Contrived Self-Defense is a case of moral dilemma. Moral dilemma happens when the agent faces two or more conflicting and unoverridden obligations that she cannot satisfy all of them, but must do one of them. Hence, she is required, and thus permitted, to do something wrong. So, moral dilemmas are wrong but permissible (Lawlor, 2009, 211). Therefore, if Contrived Self-Defense were just a case of moral dilemma, my argument would not be original.

To make Contrived Self-Defense as a case of moral dilemma, however, one must construe Mike as facing at least two conflicting obligations: presumably, the obligation of not killing a person and the obligation of protecting oneself. However, this construal of Contrived Self-Defense seems wrong. It is more plausible to say that Mike has the right to self-defense rather than that Mike has the obligation of protecting himself. Having a right to $\varphi$ only implies that one is permitted to $\varphi$ rather than one is obliged to $\varphi$. My opponents need to explain what sorts of unoverridden moral obligations Mike is facing when Don is pulling the gun on him. It is unclear that there is any. 
Furthermore, even if it is possible to construe Contrived Self-Defense as a case of moral dilemma, it is irrelevant to my point. For now, we have two kinds of Contrived Self-Defense: one is a moral dilemma, and the other involves using a right to do wrong. While the former may not be original, my case is intended to be taken as the latter and I have argued that it is original. The reason is that to make Mike's killing Don permissible, all I need is that Mike still has the right to self-defense. And my argument for Mike's right to self-defense in section 1 did not appeal to the idea that Mike is obliged to defend himself against Don's threat. So, my Contrived Self-Defense is not and needs not to be a case of moral dilemma.

That said, there is actually a moral dilemma concerning Contrived Self-Defense, though the dilemma is on the side of law enforcement. This also marks an interesting difference between Contrived Self-Defense and normal kinds of right to do wrong. Normally, we think that the rights to do wrong should be legally protected for the moral reasons given above. However, things are different with Contrived Self-Defense. Farrell $(2013,585)$ has suggested that Mike, though permitted to kill Don, ought to be punished for his wrongdoing. Unfortunately, Farrell does not say what kind of punishment Mike should receive. Nevertheless, it seems that no punishment can do justice to Mike's wrongdoing. On the one hand, the law ought to punish Mike as severely as a usual murder, but it seems unjustified because it pays lip service to the fact that his killing is permissible. On the other hand, the law ought to punish Mike considerably less severely than a usual murder, but it seems unjustified in the light of his murder (which is even more evil than ordinary murders). Either way seems unjust.

How we should deal with Contrived Self-Defense is not an issue I can fully address here. I have argued that Contrived Self-Defense is an intuitive case of permissible wrongdoing, and its moral significance merits our further exploration. ${ }^{11}$

\footnotetext{
${ }^{11}$ Acknowledgement: I would like to thank the following people for their helpful feedbacks: Hua Wang, Hahn Hsu, Peter Tsu, Ser-Min Shei, Jhih-Hao Jhang, Alex Gregory, and Daniel Whiting.
} 


\section{References}

Alexander, Larry. 2013. "Causing the Conditions of One's Defense: A Theoretical Nonproblem." Criminal Law and Philosophy 7 (3):623-628. doi: 10.1007/s11572-013-92211.

Capes, Justin A. 2012. "Blameworthiness without Wrongdoing." Pacific Philosophical Quarterly 93 (3):417-437. doi: 10.1111/j.1468-0114.2012.01433.x.

Darwall, Stephen. 2013. Morality, Authority, and Law: Essays in Second-Personal Ethics I. Oxford: Oxford University Press.

Driver, Julia. 1992. "The Suberogatory." Australasian Journal of Philosophy 70 (3):286-295. doi: 10.1080/00048409212345181.

Enoch, David. 2002. "A Right to Violate One's Duty." Law and Philosophy 21 (4):355-384. doi: 10.1023/A:1020942614528.

Farrell, Daniel M. 2013. "What Should We Say We Say about Contrived 'Self-Defense' Defenses?" Criminal Law and Philosophy 7 (3):571-585. doi: 10.1007/s11572-0139220-2.

Feinberg, Joel. 1978. "Voluntary Euthanasia and the Inalienable Right to Life." Philosophy \& Public Affairs 7 (2):93-123. doi.

Ferzan, Kimberly Kessler. 2013. "Provocateurs." Criminal Law and Philosophy 7 (3):597-622. doi: 10.1007/s11572-013-9213-1.

Finkelstein, Claire Oakes, \& Leo Katz. 2008. "Contrived Defenses and Deterrent Threats: Two Facets of One Problem." Ohio State Journal of Criminal Law 5 (479). doi.

Frowe, Helen. 2014. Defensive Killing: An Essay on War and Self-Defence. Oxford: Oxford University Press.

Frowe, Helen. 2015. "Claim Rights, Duties, and Lesser-Evil Justifications." Aristotelian Society Supplementary Volume 89 (1):267-285. doi: 10.1111/j.1467-8349.2015.00253.x.

Graham, Peter A. 2014. "A Sketch of a Theory of Moral Blameworthiness." Philosophy and Phenomenological Research 88 (2):388-409. doi: 10.1111/j.1933-1592.2012.00608.x.

Hecht, Lisa. 2019. "Provocateurs and Their Rights to Self-Defence." Criminal Law and Philosophy 13 (1):165-185. doi.

Kamm, F. M. 2012. The Moral Target: Aiming at Right Conduct in War and Other Conflicts. Oxford: Oxford University Press.

Lawlor, Rob. 2009. Shades of Goodness: Gradability, Demandingness and the Structure of Moral Theories: Palgrave Macmillan.

McNamara, Paul. 2011. "Supererogation, Inside and Out: Toward an Adequate Scheme for Common Sense Morality." In Oxford Studies in Normative Ethics, edited by Mark Timmons, 202-235. Oxford: Oxford University Press.

Quong, Jonathan. 2015. "Rights Against Harm." Aristotelian Society Supplementary 89 (1):249266. doi: 10.1111/j.1467-8349.2015.00252.x.

Scanlon, T. M. 2008. Moral Dimensions: Permissibility, Meaning, Blame. Cambridge, MA: Belknap Press.

Waldron, Jeremy. 1981. "A Right to Do Wrong." Ethics 92 (1):21-39. doi: doi:10.1086/292295. 